\title{
METODE BERCERITA DENGAN TEKNIK ROLE- PLAYING UNTUK MENUMBUHKAN AKHLAK MULIA
}

\author{
Ari Kartiko \\ Institut Pesantren KH Abdul Chalim Pacet Mojokerto \\ Ari.kartiko5@gmail.com \\ Edy Kurniwan \\ Institut Pesantren KH. Abdul Chalim Pacet Mojokerto \\ edykurniawan2497@gmail.com
}

\begin{abstract}
Education plays an important role in achieving the ideals of the Indonesian people in accordance with the formulation of the 1945 Constitution which clearly states that the purpose of education is to promote public welfare and educate the life of the nation, essentially the realization of these noble individuals of course it will balance the nation's intelligence in prospering the country. Based on this, education must be able to foster noble character so that later can produce generations that are intelligent and useful for the nation. The problem lies in how to cultivate noble character in students. School institutions by means of teacher teaching are central to instilling students' noble character. Therefore this study aims to find out how storytelling and role-playing activities can foster noble character. This study uses qualitative research with the type of research library. Research libraries are research techniques using book sources to develop science. Clear information and sources have been arranged systematically. Storytelling with role-playing techniques is something that students really like. This will be learning that can stimulate student activity. Inserting values into a story will be useful in developing noble character. Noble character is a sincere and conscious act that arises from within a person. By telling stories, students will get knowledge about good grades and role-playing will provide opportunities for students to apply the knowledge gained. So that it will become good habits and emerge noble character in students.
\end{abstract}

Nazhruna: Jurnal Pendidikan Islam

Vol. 1 No 2 Agustus 2018. Issn: 2614-8013. Hal. 201-222 
Keywords: Strorytelling, Role-playing. Noble Character

\begin{abstract}
Abstrak
Pendidikan sangat berperan penting dalam mencapai cita-cita bangsa Indonesia sesuai dengan rumusan UUD 1945 yang tertulis secara jelas bahwa tujuan pendidikan yaitu untuk memajukan kejahteraan umum dan mencerdaskan kehidupan bangsa, intinya perwujudan individu yang berakhlak mulia ini tentunya akan mengimbangi kecerdasan bangsa dalam mensejahterahkan negara. Berdasarkan hal tersebut, pendidikan harus bisa menumbuhkan akhlak mulia agar nantinya bisa menghasilkan generasi-generasi yang cerdas dan berguna bagi bangsa. Permasalahannya terletak pada cara menumbuhkan akhlak yang mulia pada siswa. Lembaga sekolah dengan cara pengajaran guru adalah inti dalam menanamkan akhlak mulia siswa. Oleh karena itu kajian ini bertujuan untuk mengetahui bagaimana kegiatan bercerita dan role playing dapat menumbuhkan akhlak mulia. Penelitian ini menggunakan penelitian kualitatif dengan jenis library riset. Library riset adalah tehnik meneliti dengan menggunakan sumber buku untuk mengembangkan ilmu pengetahuan. Informasi dan sumber yang jelas telah disusun secara sistematis. Bercerita dengan teknik role playing adalah hal yang sangat disenangi siswa. Hal ini akan menjadi pembelajaran yang dapat merangsang keaktifan siswa. Penyisipkan nilai-nilai kedalam suatu cerita akan bermanfaat dalam menumbuhkembangkan akhlak mulia. Akhlak mulia adalah suatu perbuatan baik secara ikhlas dan sadar yang muncul dari dalam diri seseorang. Dengan bercerita maka siswa akan mendapat ilmu tentang nilai yang baik dan role playing akan memberikan kesempatan bagi siswa untuk menerapkan ilmu yang diperolehnya. Sehingga akan menjadi kebiasaan baik dan muncul akhlak mulia dalam diri siswa.
\end{abstract}

Kata kunci: bercerita, role playing, akhlak mulia 


\section{Pendahuluan}

Pendidikan di sekolah telah menjadi kewajiban seluruh bangsa Indonesia. Wajib belajar 9 tahun telah diatur dalam UU No. 20 Tahun 2003 Pasal 3 tentang Sistem Pendidikan Nasional yang berfungsi mewujudkan negara demokratis dan bertanggung jawab dengan keseimbangan watak ataupun akhlak mulia dan kecerdasan keilmuan siswa.

Di era sekarang banyak terjadi permasalahan-permasalahan yang dihadapi oleh negara kita yang diakibatkan kurangnya akhlak dari generasi penerus bangsa seperti, korupsi dan penyalahgunaan wewenang dalam bertugas. Output dari suatu lembaga pendidikan sangat memprihatinkan karena tidak sejalan dengan tujuan pendidikan. Telah banyak masyarakat Indonesia yang menjadi korban pejabat cerdas tetapi tidak berakhlak. Hal ini diakibatkan karena proses pendidikan yang kurang menekankan nilai dalam proses pembelajaran.

Sebaiknya permasalahan yang melanda negara kita dapat diatasi dengan pendidikan. Jika pendidikan dapat menjalankan peranannya dengan baik maka tujuan pendidikan dapat tercapai secara rill. Sehingga output generasi penerus bangsa mampu membangun negara ini. Akhlak yang tertanam dalam jiwa manyarakat Indonesia akan meminimalisir terjadinya permasalahan seperti korupsi, bolos kerja dan sebagainya.

Dalam dunia pendidikan terdapat banyak faktor penentu keberhasilan siswa seperti metode yang digunakan guru dalam mengajar. Metode adalah cara guru menyampaikan ilmu kepada siswa. Penerapan metode belajar sebaiknya disesuaikan dengan karateristik seluruh siswa di dalam kelas. Sehingga proses belajar mengajar berjalan efektif dan efisien.

Sekolah Madrasah Ibtidaiyah (MI) adalah lembaga formal pertama yang menjadi tempat belajar siswa. Rata-rata umur siswa di MI yaitu antara 7-12 tahun. Usia ini adalah masa keemasan siswa sehingga sangat cocok untuk menanamkan pondasi nilai serta ilmu pengetahuan. 
Akan tetapi dalam proses pembelajaran sangat perlu kehati-hatian karena siswa MI cenderung menirukan apa yang telah dilihatnya.

Karakteristik siswa secara umum di sekolah Madrasah yaitu suka bermain dan mendengar cerita. Siswa MI yang merasa senang dalam proses pembelajaran lebih mudah dalam menangkap ilmu. Seyogyanya seorang guru MI harus mampu menetapakan langkah pembelajaran dengan unsur cerita dan bermain di dalamnya sehingga tujuan pembelajaran dapat tercapai secara efektif dan efisien.

Bercerita dalam proses pembelajaran sebaiknya berisi nilai moral agar siswa mendapat pengetahuan nilai. Dengan pengetahuan tersebut siswa akan terapresiasi melakukan suatu perbuatan baik. Seorang guru harus mampu mengetahui keinginan siswa untuk bertindak sehingga dalam proses pembelajaran bisa memanfaatkannya untuk memaksimalkan pencapaian tujuan.

Teknik Role playing dalam bercerita adalah teknik yang cocok untuk mengimplementasikan tindakan-tindakan siswa. Role playing biasa dikenal sebagi siswa bermain peran. Dalam strategi dengan teknik ini siswa diberi kesempatan untuk mengapresiasikan nilai dan ilmu yang telah diterimanya. Sehingga dapat merangsang siswa aktif dalam pembelajaran.

Dengan menggunakan strategi bercerita dengan teknik role playing akan mengfektifkan tujuan pembelajaran dan penanaman nilai untuk membentuk akhlak mulia. Akhlak mulia adalah tindak sadar seseorang untuk melakukan suatu perbuatan baik. Siswa yang berakhlak mulia akan menjadi generasi yang sempurna untuk membangun bangsa. 


\section{Pembahasan}

\section{Bercerita}

Menurut Ismoerdijahwati yang dikutip ${ }^{1}$ bahwa bercerita merupakan seni penyampaian nilai dari suatu peristiwa melalui perkataan yang didesain sedemikian rupa dengan kemampuan berimajinasi seorang pencerita. Menyampaikan suatu hal yang penting dengan cerita yang telah disusun rapi kepada seseorang disebut juga bercerita. Bercerita adalah penyampain atau pembawaan cerita secara lisan kepada seseorang. Dalam pembelajaran bercerita adalah sebuah metode atau langkah yang dilakukan untuk menyampaikan materi pelajaran. Metode adalah langkah yang tersusun sistematis dalam menyampaikan pengembangan tertentu. Metode bercerita adalah penyampaian pelajaran melalui cerita secara lisan dengan menambah pengalaman belajar berupa nilai-nilai akhlak ${ }^{2}$.

Hal-hal yang menarik dalam cerita yaitu dapat menghasilkan berbagai macam perasaan, imajinasi yang menyentuh hati sehingga memunculkan perasaan kuat yang dapat menggerakkan seseorang untuk melakukan sesuatu. Itulah mengapa cerita menjadi suatu sumber/bahan popular guru dalam membentuk dan mengebangkan akhlak mulia siswa ${ }^{3}$.

Secara umum siswa MI menyukai cerita bahkan telah menjadi favorit siswa. Tim Kent sebagai seorang guru akhlak di SD Dry Creek, California. Dari pengalaman Tim Kent yang mengidolakan metode ini mampu mengefektifakan pembelajaran karena antusias siswa dalam mendengar cerita sangat tinggi. Tema cerita yang sering digunakan oleh Tim Kent yaitu cerita tentang apa yang diminati para siswanya seperti cerita Cinderella, Toys Story, Reader Digets daln lain-lain. Tim Kent

\footnotetext{
${ }^{1}$ Muzdalifah M. Rahman, Metode Bercerita Membentuk Kepribadian Muslim Pada Anak Usia Dini (ThufuLa, 2013), 76.

2 Try Setiantono, 'Penggunaan Metode Bercerita Bagi Anak Usia Dini Di Paud Smart Little Cilame Indahbandung', Empowerment 1, no. 2 (2018): 22.

${ }^{3}$ Thomas Lickona, Educating for Character: How Our Schools Can Teach Respect and Responsibility (New York: Bantam Books, 2009), 87. 
beranggapan bahwa bercerita adalah salah satu instrument pengajaran yang palin penting dan dapat mengalihkan perhatian siswa.

Dongeng salah satu bentuk cerita yang sering digunakan dalam pembelajaran ${ }^{4}$. Dongeng berisi suatu kebudayaan yang mangandung berbagai ilmu pengetahuan dan nilai-nilai akhlak. Bentuk cerita dongeng sangat cocok digunakan dalam pembelajaran di MI karena dapat menambah pengalaman dan wawasan tentang nilai akhlak sebagai landasan untuk ke jenjang yang lebih tinggi. Menurut Tampubolon bahwa "isi cerita sebaiknya disesuaikan dengan jenjang pendidikan serta pengalaman siswa". Pendapat ini bertujuan agar cerita dapat dipahami dan dimaknai oleh siswa. Ketika pemahaman cerita oleh siswa baik maka begitu pula dengan penangkapan nilai-nilai yang terdapat dalam cerita.

\section{Manfaat dan Tujuan bercerita.}

Manfaat metode bercerita bagi siswa:

a.) Menjadi pemicu otak siswa dalam berfikir kritis untuk mampu memahami isi suatu cerita.

b.) Membantu meningatkan daya konsentrasi siswa dalam memusatkan perhatiannya kepada keseluruan cerita tersebut.

c.) Mengembangkan daya imajinasi siswa yang mampu meningkatkan kemampuan otak kanan siswa lebih produktif sehingga mudah mengolah informasi.

d.) Bercerita dapat menambah pengalaman belajar siswa dalam mendengarkan dan menyimak cerita.

e.) Penyampaian cerita yang baik oleh guru dapat menambah kosa kata bahasa siswa sehingga memudahkan kemampuan berkomunikasi.

f.) Mengembangakan jiwa sosial siswa. Cerita yang disusun dengan melibatkan beberapa tokoh didalamnya mencerminkan kehidupan sosial dan kebersamaan.

\footnotetext{
${ }^{4}$ Rahman, Metode Bercerita Membentuk. Kepribadian Muslim Pada Anak Usia Dini, 76.
} 
g.) Mengembangkan akhlak mulia siswa dengan menanamkan nilainilai akhlak kedalam cerita.

h.) Mengembangkan empati siswa. Empati adalah kemampuan untuk mengetahui dan merasakan keadaan yang dialami orang lain.

i.) Mengembangkan kecerdasan emosioanl siswa. Kecerdasan emosional yaitu gabungan dari kemampuan sosial-emosional siswa. Siswa yang memiliki kecerdasan emosional siswa akan mampu mengontrol diri atau emosinya sehingga mampu mengungkapkan perasaannya dengan baik.

Menurut pendapat Dhieni yang dkutip ${ }^{5}$ menyatakan bahwa, tujuan metode bercerita bagi siswa yaitu agar (a) siswa dapat mendengarkan secara seksama dan memperhatikan guru, (b) siswa dapat bertanya tentang cerita yang diceritakan guru, (c) siswa dapat menceritakan kembali serta mengeskpresikan cerita yang telah didengarkannya. Tentunya masih ada lagi tujuan dalam bercerita seperti agar siswa mampu menyimak isi dan nilai-nilai moral yang terdapat dalam cerita

Dari pemaparan diatas tentang tujuan dan manfaat bercerita yaitu untuk mengefektifkan pembelajaran dengan memperhatiakan ketiga aspek kemampuan siswa yakni kemampuan kognitif, afektif dan spikomotor siswa.

\section{Langkah-Langkah Bercerita.}

Menurut Dhieni ${ }^{6}$ pelaksanaan metode bercerita disusun menjadi lima langkah antara lain:

1) Mengelolaan tempat duduk siswa, ketika siswa merasa rileks dan nyaman maka siswa akan betah ketika mendengarkan

${ }^{5}$ Pebri Damaryanti Ni Putu et al., 'Efektivitas Metode Bercerita Dengan Media Boneka Wayang Terhadap Kemampuan Bercakap-Cakap Anak Kelompok B Di Tk Widya Sesana Sangsit Tahun Pelajaran 2016/2017', Jurnal Pendidikan Anak Usia Dini Undiksha 5, no. 1 (2017): 6.

${ }^{6}$ Ida Ayu Komang Sri Widianti et al., 'Penerapan Metode Bercerita Dengan Media Gambar Untuk Meningkatkan Keterampilan Berbicara Pada Anak', Jurnal Pendidikan Anak Usia Dini Undiksha 3, no. 1 (2015): 4. 
cerita. Aktivitas bercerita tidak harus dilakukan di dalam kelas. Kegiatan cerita dapat dilakukan di mana saja, asal memenuhi kriteria kebersihan, keamanan, dan kenyamanan.

2) Memberikan kesempatan kepada siswa untuk mengajukan judul cerita, sebelum siswa mengetahui judul cerita sebenarnya.

3) Menentukan tema atau judul cerita. yaitu ${ }^{7}$ :

Hal yang perlu diperhatikan dalam pemilihan cerita

a) Cerita sebaiknya menarik dan memikat perhatian siswa dan guru itu sendiri.

b) Cerita disesuaikan dengan gaya kepribadian dan jenjang pendidikan siswa

c) Cerita berdasarkan kehidupan di lingkungan siswa sehingga mudah mencerna isi cerita.

4) Bercerita.

Selain penggunaan media, dalam bercerita seorang guru harus memiliki keterampilan bercerita yaitu, bagaimana mengekspresikan gerak dan suara dan raut muka guru sesuai dengan karakter tokoh dalam cerita serta cara menenangkan siswa.

5) Memberi kesempatan kepada siswa untuk bertanya dan menarik kesimpulan. Langkah ini untuk mengetahui sampai mana perhatian siswa terhadap cerita yang telah disampaikan sebagai bentuk penilaian dalam pembelajaran

Dari penjelasan diatas dapat diketahui bahwa ada empat elemen penting yang perlu dikuasai oleh guru yaitu pengelolaan kelas,

\footnotetext{
${ }^{7}$ Mursid, Pengembangan Pembelajaran PAUD (Bandung: Remaja Rosdakarya, 2015), 33.
} 
pemilihan tema atau judul cerita, keterampilan bercerita, serta cara penilaian hasil pembelajaran.

Kelebihan metode cerita menurut ${ }^{8}$ yaitu:

a. Dapat diterapkan pada kelas yang memiliki banyak siswa.

b. Pengelolaan yang baik akan mengefektifkan pembelajaran.

c. Mudah dalam penguasaan kelas.

d. Tidak terlalu banyak menggunakan biaya.

Kekurangan metode bercerita tanpa penggunaan teknik

a. Bersifat teacher center sehingga siswa menjadi pasif

b. Kurang berkembangnya kreatifitas siswa karena hanya focus mendengarkan cerita tanpa ada tindak lanjut prakteknya.

c. Keberhasilan pembelajaran sangat ditentukan oleh kemampuan seorang guru dalam bercerita.

\section{Role Playing}

Menurut Wilson bahwa role playing sering diterapkan dalam kehidupan sehari-hari yaitu dari kemampuan seseorang mengespresikan pengalamannya dalam bentuk model ${ }^{9}$. Role playing merupakan pementasan drama bersifat sederhana yang bertujuan sebagai tempat untuk siswa mengekspresikan pandangannya. Artinya bahwa teknik role playing sebagai cara yang menjadi wadah siswa dalam bertindak sebagai model di dalam kelas. Dalam role playing telah diatur bagaimana dalam menjadi model dan memerankan tokoh yang telah ditentukan.

\footnotetext{
${ }^{8}$ Ni Kadek Ayu Mekarningsih, Nyoman Wirya, and Mutiara Magta, 'Penerapan Metode Bercerita Berbantuan Media Audio Visual Untuk Meningkatkan Kemampuan Berbahasa Lisan Pada Anak', Jurnal Pendidikan Anak Usia Dini Undiksha 3, no. 1 (2015): 4.

9 Imam Baihaqi, 'Peningkatan Keterampilan Bermain Drama Dengan Metode Role Playing Pada Kelompok Teater Kenes SMPN 4 Yogyakarta', Transformatika: Jurnal Bahasa, Sastra, Dan Pengajarannya 12, no. 2 (2016): 7. 
Menurut Adam Blatner, M.D, yang dkutip oleh 10 mengemukakan bahwa Role Playing disebut juga sebagai sosiodrama yang merupakan sebuah metode mengulang kembali sesuatu yang dianggap penting dalam kaitannya dengan hubungan masalah social. Tujuannya untuk mengetahui apa saja yang salah serta apa hikmah yang dapat dipetik dari pengulangan itu.

${ }^{11}$ mengemukakan tujuan penggunaan role playing adalah:

1) Siswa dapat belajar menghargai perasaan orang lain dengan sehingga muncul rasa saling toleransi.

2) Memunculkan rasa tanggung jawab siswa atas peran yang telah diberikan dalam kelompok.

3) Menanamkan kerjasama yang baik sebagai individu demokratis.

4) Merangsang siswa secara keseluruhan untuk berfikir kritis dalam memecahkan masalah.

Dari pendapat Sutoso bahwa penggunaan metode role playing memiliki beberapa kelebihan, yaitu sebagai berikut.

1) Permainan yang diperankan sendiri, membantu dalam memahami masalah - masalah yang sedang dihadapi

2) Siswa dapat menempatkan dirinya sendiri seperti halnya watak tokah dari karakter yang dimainkan.

3) Mampu merasakan perasaan yang dialami oleh orang lain. Hal tersebut mampu menumbuhkan sikap saling menghargai dan toleransi terhadap sesama.

${ }^{10}$ Kiromim Baroroh, 'Upaya Meningkatkan Nilai-Nilai Karakter Peserta Didik Melalui Penerapan Metode Role Playing, Jurnal Ekonomi \& Pendidikan 8, no. 2 (2011): 150.

11 Djamarah Syaiful Bahri and Aswan Zain, Strategi Belajar Mengajar (Jakarta: Rineka Cipta, 2010). 


\section{Langkah-Langkah Teknik Role Playing}

Menurut ${ }^{12}$ bahwa pelaksanaan role playing disusun menjadi empat tahap yaitu tahap persiapan, pelaksanaan, penilaian dan penutup. Keempat tahap dijelaskan sebagai berikut:

1. Tahap Persiapan

Persiapan adalah langkah awal yang memiliki peran yang sangat penting untuk mengefektifkan pelaksanaan role playing. Langkah dalam menyusun persiapan sebagai berikut.

a. Menetapakan latar belakang masalah yang awalnya terdapat pada cerita untuk dilakukan oleh siswa.

Dalam menetapkan / menentukan latar belakang masalah sebaiknya seorang guru mengerti terlebih dahulu karakteristik dari seluruh siswa agar dapat mengetahui dengan baik permasalahan apa yang cocok dan diminati oleh siswa.

b. Guru menyusun dan menyiapkan scenario cerita dan peran siswa dalam melakukan role playing.

Penyusunan scenario lebih baiknya dilakukan bersamasama dengan siswa agar siswa dapat aktif dalam menyumbangkan ide dan gagasannya. Keterlibatan siswa akan memudahkan dalam mengikuti kegiatan selanjutnya.

c. Menetapkan peran yang akan dimodelkan oleh siswa.

Menetapkan peran bagi masing-masing siswa adalah hal yang sedikit rumit karena guru harus mengerti setiap karakter siswa agar ada kesesuaian dengan peran tokoh yang didapatnya. Oleh karena itu penetapan ini harus diadakan secara bersama-sama dengan siswa agar guru

${ }^{12}$ Uno Hamzah B, Profesi Kependidikan, Problema, Solusi Dan Reformasi Di Indonesia, 7 (Jakarta: Bumi Aksara, 2011). 
mendapat ide tambahan dari siswa karena siswa sebagai teman sekelasnya pasti lebih mengerti.

d. Siswa dibentuk menjadi beberapa kelompok bagian

Pembagian kelompok ini bertujuan untuk menyesuaikan dan memudahkan siswa dalam berlatih peran. Pembagian kelompok ini dapat membentuk rasa saling membantu dan menghargai siswa.

2. Tahap Pelaksanaan

a. Guru menyampaikan standar kompetensi dan tujuan pembelajaran yang diharapakan setelah melaksanakan role playing.

Penyampaian SK dan tujuan pembelajaran diawal pelaksanaan berguna untuk mengarahkan siswa tentang apa saja yang akan dicapai setelah melakukan kegiatan role playing.

b. Siswa yang telah dibagi dalam beberapa kelompok disatuakan berdasarkan kelompoknya masing-masing.

Penyatuan siswa berdasrkan kelompoknya bertujuan untuk menyiapkan mental siswa dengan melihat dan mengamati kembali scenario yang akan dilakukannya.

c. Melaksanakan teknik role playing dengan didalangi oleh seorang guru sesuai dengan cerita.

Artinya bahwa seorang guru dalam pelaksanaan role playing tidak hanya diam mengamati dan menilai siswa tetapi juga mengambil peran yaitu sebagai dalang. Dalang adalah orang yang bertugas mebacakan alur cerita agar cerita berjalan dengan efektif dan efisien.

3. Tahap Penilaian

a. Pemberian lembar kerja siswa untuk menyimpukan hasil dari kegiatan role playing. 
Kegiatan ini bertujuan untuk mengukur seberapa paham siswa tentang pelajaran yang telah dilakukan sebelumnya dengan penggunaan metode role paying.

b. Memberi kesempatan beberapa siswa untuk menyampaikan hasil kesimpulan yang telah dituliskan.

Kegiatan ini bertujuan untuk memantapkan pengetahuan siswa dan sebagai langkah untuk mengembangkan nilai tanggung jawab dengan apa yang telah dituliskanya.

c. Guru menyampaikan kesimpulan sebenarnya secara umum.

Penyampaian kesimpulan oleh guru bertujuan untuk memberi tahu siswa secara jelas bagaimana cara menyimpulkan dengan baik dan memahamkan siswa agar pengetahuan siswa tidak keliru dan beragam.

4. Penutup

a. Evaluasi.

Kegiaan evaluasi bertujuan untuk mengetahui tingakt efektif dan efisiensi sitem pembelajaran yang telah digunakan sebelumnya. Sitem pembelaran yang dimaksud yaitu berupa metode role playing yang diguanakan, tujuan, sumber belajar dan lain-lain. Evaluasi ini dilakukan agar kegiatan selanjutnya bisa berjalan lebih baik.

\section{Akhlak Mulia}

Pengertian akhlak menurut Imam Abu Hamid al-Ghazali bahwa akhlak adalah sifat dan kelakuan yang berasal dari lubuk hati paling dalam manusia tanpa dipengaruhi oleh akal terlebih dahulu. Jika sifat yang dimunculkan seseorang baik maka disebut akhlak baik 
atau akhlak mulia sedangkan jika sifat yang muncul buruk maka disebut akhlak buruk ${ }^{13}$.

Menurut Halim bahwa akhlak atau moral mempunyai empat makna yaitu moral yang berarti sekumpulan aturan yang disepakati oleh seseorang untuk membentuk perbuatan yang dinilai baik berdasarkan syarat, filsafat, dengan tujuan agar tercipta kehidupan humanism

Jadi, akhlak mulia adalah segala sesuatu yang dimunculkan oleh jiwa seseorang untuk melakukan suatu perbuatan baik dalam situasi sadar. Akhlak mulia yaitu sifat terpuji yang dapat mencegah sifat-sifat tercela terjadi pada kehidupan manusia. Akhlak juga bisa disebut akarakter, akan teteapi akaakter cenderung melakukan hal baik sedangkan akhlak bisa berupa baik da buruk ${ }^{14}$.

Manusia yang memiliki akhlak mulia adalah kebanggaan bagi dirinya serta masyarakat sekitarnya. Dengan akhlak yang mulia dalam diri manusia dapat berdampak pada terjalinnya interaksi positif sehingga terjadi perdamain dan kenyamanan social. Kenyamanan dalam lingkungan sekolah adalah harapan bagi seluruh anggota lembaga pendidikan. Tentunya dengan ini maka akan memudahkan pencapaian tujuan karena kerukunan seluruh anggota lembaga sekolah.

Output lembaga sekolah yang berakhlak mulia nantinya akan mengembangakan negara dan menghilangkan kasus-kasus penghambat negara menuju kemakmuran. Generasi-generasi penerus yang nantinya akan menanamkan nilai akhlak sebagai dasar pendidikan yang juga merupakan tujuan penddikan inti di Indonesia.

${ }^{13}$ Sabar Budi Raharjo, 'Pendidikan Karakter Sebagai Upaya Menciptakan Akhlak Mulia', Jurnal Pendidikan dan Kebudayaan 16, no. 3 (10 May 2010): 233, https://doi.org/10.24832/jpnk.v16i3.456.

14 Muhammad Anas Ma arif, 'Analisis Strategi Pendidikan Karakter Melalui Hukuman Preventif, Ta'allum: Jurnal Pendidikan Islam 6, no. 1 (6 March 2018): 38, https://doi.org/10.21274/taalum.2018.6.1.31-56. 


\section{Analisis Strategi Bercerita Dengan Teknik Role Playing untuk Menumbuhkan Akhlak Mulia}

Dalam pembelajaran strategi bercerita telah terbukti mampu mengembangkan akhlak mulia siswa. Penyisipan nilai-nilai ke dalam cerita akan menjadi nilai plus strategi ini. Selain itu, strategi bercerita juga sangat disenangi oleh siswa dalam pembelajaran karena cerita dianggap hal yang menyenangkan. Namun metode bercerita klasik yang sederhana dengan menggunakan buku cerita masih dianggap kurang cocok karena memiliki banyak kekurangan.

Sesuai dengan perkembangan keilmuan dalam lingkup metode pembelajaran telah dikembangkan teknik baru yang bisa menutupi kekurangan dari metode cerita. Salah satu tekniknya yaitu teknik role playing, penggunaan buku cerita dan penggunaan boneka dalam bercerita.

Teknik bercerita yang popular digunakan yaitu penggunaan buku cerita, boneka. Metode ini memang cocok bagi siswa MI/SD karena penggunaan alat peraga berupa boneka yang dapat merilkan tokoh cerita yang abstrak. Namun menurut saya teknik ini kuang efektif dalam pembelajaran karena siswa hanya melihat dan mendengarkan cerita. Sehingga yang tercapai hanya pada tujuan kognitif dan afektifnya saja. Sedangkan tujuan spikomorik siswa tidak tercapai. Jika ketiga aspek tersebut itu tidak tercapai maka sulit dalam membentuk akhlak mulia siswa

Metode bercerita secara umum masih memiliki beberapa kekurangan seperti jika bercerita tanpa pengunaan teknik maka siswa hanya mampu mengembangkan kemampuan mendengar dan melihatnya saja dan ini tidak cukup untuk menumbuhkan akhlak mulia siswa. Oleh karena itu pengembang menggunakan teknik role playing dalam metode bercerita akan meminimalisir dan bahkan menghilangkan kekurangan-kekurangan tersebut. Teknik role playing menjadi wadah siswa untuk mendramakan cerita yang didengarnya sehingga siswa yang awalnya pasif menjadi aktif. Siswa juga lebih kreatif dalam menyampaikan pendapatnya. 
Penggunaan teknik role playing yang bermodel cooperative dapat meningkatkan kompetensi social siswa ${ }^{15}$. Kompetensi social yang dimaksud yaitu kemampuan siswa dalam (a) memahami perasaan orang lain (b) peningkatan keterampilan komunikasi (c) meningkatkan kerjasama dalam bermain peran dan (d) meningkatnya tanggung jawab atas peran dan aturan.

Oleh karena itu keefektifan metode bercerita ini dengan teknik role playing tidak diragukan lagi dalam meningkatkatkan akhlak mulia siswa karena dalam setiap cerita terdapat pesan akhlak yang berisikan nilai-nilai berempati. Nilai-nilai yang disisipkan kedalam cerita menjadi pengetahuan akhlak bagi siswa. Kemudian dari pengetahuan akhlak muncul keinginan untuk berbuat baik dan akhirnya teraplikasilah akhlak tersebut dalam suatu tindakan.

Penanaman nilai-nilai akhlak kedalam jiwa siswa juga dipengaruhi oleh fungsi guru sebagai fasilitator dan komunikator ${ }^{16}$. Artinya bahwa dalam proses pembelajaran tugas seorang guru tidak hanya sebagai pengajar akan tetapi juga memfalisitasi dan berkomunikasi hangat dengan siswa. Jika seorang guru dapat menjalankan tuganya dengan baik maka siswa dapat menerima pelajaran dan nilai-nilai akhlak secara efektif dan efisien.

Akhlak dalam pandangan islam titik dasar yang menjadi landasan tentang perhitungan dan penilaian baik buruknya sesuatu. Landasan bukan berdasarkan pandangan manusia akan tetapi pada perintah dan larangan Allah SWT, oleh karena itu akhlak yang baik muncul dari kepatuhan dan ketaatan hanya kepada Allah SWT. Pertimbangan itu didasarkan dari salah satu ayat dalam QS. An-Nisa dan QS Al Ahzab yang artinya:

${ }^{15}$ Dwi Bhakti Indri M, 'Religious Spirituality - Cognitive Behaviour Therapy Untuk Meningkatkan Self-Confidence Dalam Social Interaction Anak Usia Dini', Nidhomul Haq : Jurnal Manajemen Pendidikan Islam 1, no. 3 (2016): 162-78, https://doi.org/10.31538/ndh.v1i3.15.

${ }^{16}$ Muhammad Anas Ma arif, 'Pendidikan Islam Dan Tantangan Modernitas', Nidhomul Haq: Jurnal Manajemen Pendidikan Islam 1, no. 2 (26 March 2016): 50. 
"Hai orang-orang yang beriman, taatilah Allah dan taati Rasul-Nya dan Ulil Amri diantara kamu, kemudian jika kamu berlainan pendapat tentang sesuatu maka kembalikanlah ia kepada Allah (Al-Qur'an) dan Rasul (sunnahnya) jika kamu benar-benar beriman kepada Allah dan hari akbir, yang demikian itu lebih utama (bagimu) dan lebih baik akibatnya.” (An-Nisa: 59)

"Sesunggubnya telah ada pada (diri) Rasulullah itu suri teladan yang baik bagimu (iaitu) bagi orang yang mengharap (rahmat) Allah dan (kedatangan) hari kiamat dan dia banyak menyebut Allab." (QS Al Abrab: 21)

Dari kedua ayat tersebut dapat disimpulkan bahwa akhlak yang baik telah tercontoh pada diri Rasululluh, baik dari tutur kata maupun perbuatan.

Salah satu ilmu yang merujuk dan memiliki kesamaan dengan akhak mulia yaitu ilmu tasawuf. Dalam ilmu tasawuf soseorang berusaha mensucikan diri dengan berbuat baik agar bisa mencapai zuhud. Zuhud adalah meninggalkan akhlak yang dipandang buruk oleh Allah SWT. Segala sesuatu yang dipandang baik oleh Allah maka akan dipandang baik juga oleh sesama manusia. Ilmu Akhlak dengan Ilmu Tasawuf itu saling berkaitan satu sama lain. Dalam hal ini tampak pada nilai-nilai yang sama dalam hal takwa kepada sang pencipta.

Sebagai umat beriman kita harus mencontoh suri tauladan Rasulullah. Untuk mengetahui apasaja yang dilakukan olehnya maka banyak al-kitab yang menyajikannya. Namun pada siswa MI pastinya akan bosan jika mereka harus dibacakan kitab tersebut dalam pembelajaran. Oleh karena itu teknik bercerita dengan role playing dalam pembelajaran sangat baik untuk membentuk akhlak mulia.

Bercerita tentang kisah para nabi dapat memunculkan apresiasi siswa dalam berbuat baik. Apresiasi siswa harus ditampung dalam suatu konsep pembelajaran agar bisa teraplikasi langsung dalam pembelajaran bahkan berefek kedepannya saat di berada di luar kelas. 
Teknik role playing adalah wadah yang dapat untuk mengaplikasikan tindakan siswa.

Dalam dunia pendidikan akhlak mulia adalah salah satu tujuan pendidikan nasional. Banyak yang beranggapan bahwa jika akhlak mulia siswa sudah tercapai makan tujuan pendidikan telah tercapai pula. Hakikat pendidikan adalah persiapan dengan mendapingi siswa untuk mengembangkan jiwa dan ilmu pengetahuan.

Ilmu social atau disebut sebagai sosiologi juga berkaitan dengan pembentukan akhlak mulia siswa. Ilmu sosiologi yang menekankan pada hidup manusia dalam bermasyarakat, baik dari cara berinteraksi dengan masyarakat lainya. Dasar ilmu sosiologi ini terletak pada bagaimana manusia bisa bertahan hidup dalam suatu kelompok masyarakat. Oleh karena itu seorang manusia harus memiliki akhlak yang baik sehingga mudah diterima oleh masyarakat disekitarnya. Dalam ilmu akhlak memberikan konsep dan gambaran kepada seseorang tentang bentuk masyarakat yang ideal mengenai perilaku seseorang dalam masyarakat.

Pengembangan keilmuan tentang metode pembelajaran bercerita sejalan dengan penelitian yang dilakukan oleh ${ }^{17}$. Dalam penelitian ini membuktikan besarnya peranan model bercerita dalam mengembangkan nilai-nilai moral seperti pada aspek menghargai teman, peningkatan sopan santun, dan pada pengembangan tanggung jawab siswa. Berbagai macam cara untuk membentuk akhlak mulia baik secacar intrinsik dan ektrinsik. Termasuk dengan metode bercerita sekaligu dengan metode keteladanan. Berikut menurut Irawati Istadi yang di kutip oleh ${ }^{18}$ adalah hal yang bisa menimbulkan motivasi intrinsik peserta didik antara lain: 1) Memberikan pujian dengan cara yang benar 2) Memberikan pemahaman terhadap akar

\footnotetext{
${ }^{17}$ Mega Yulianti, 'Peranan Metode Bercerita Dalam Mengembangkan Nilai-Nilai Moral Pada Anak Di Kelompok B2 TK Pertiwi Palu', Bungamputi 2, no. 3 (2012).

18 Muhammad Anas Ma'arif, 'Hukuman (Punishment) Dalam Perspektif Pendidikan Di Pesantren', Ta'allum: Jurnal Pendidikan Islam 5, no. 1 (1 June 2017): 13, https://doi.org/10.21274/taalum.2017.5.1.1-20.
} 
permasalahan yang sebenarnya 3) Tidak memaksa tetapi terus memotivasi peserta didik.

Meskipun pada penelitian sebelumnya tentang pengaruh metode bercerita pada pengembangan nilai-nilai moral siswa, tapi saya beranggapan bahwa adanya kemiripan antara nilai-nilai moral dengan akhlak mulia. Sesuai dengan pendapat Wantah dalam Webster's new World dictionary yang menyatakan bahwa moral adalah sesuatu yang berhubungan atau berkaitan dengan kemampuan dalam menentukan benar atau salah dan baik buruknya tingkah laku. Kemudian dilanjutkan dengan argumen Chaplin dalam kamus psikologi bahwa moral itu mengacu pada akhlak yang memiliki kesesuaian dengan peraturan social, atau adanya keterikatan pada hukum atau adat istiadat yang menjadi kebiasaan dalam bertingkah laku ${ }^{19}$. Dari pendapat itu, saya menyimpulkan bahwa moral dan akhlak adalah hal yang memiliki kesamaan, seperti sama-sama berhubungan dengan baik buruknya tingkah laku, benar salahnya tingkah laku, keyakinan dan juga dampaknya pada lingkungan social masyarakat. Oleh karena itu saya berusaha mengembangkan keilmuan dari saran peneliti sebelumnya untuk memakasimalkan metode bercerita dengan pengguanaan teknik bercerita yang dapat meningkatkan antusias dan keaktifan siswa. Teknik yang saya gunakan yaitu metode role playing.

Teknik role playing juga terbukti dapat meningkatkan akhlak mulia siswa. Pada penelitian terdahulu oleh Kiromim Baroroh tentang penerapan role paying untuk meningkatkan karakter siswa. Hasil dari penelitian ini menunjukkan bahwa role playing dapat meningkatkan karakter disiplin, kerja keras, kreatif, dan komunikatif siswa yang menjadi bagian dari cerminan akhlak mulia siswa. Dilihat dari sudut pandang sifat dan sikap perilaku yang dihasilkan karakter, moral dan akhlak mulia tidak bisa dibedakan karena sama-sama mewujudakan manusia-manusia yang berperilaku baik serta bermanfaat bagi dirinya dan masyarakat sekitarnya.

19 Dian Ibung, Mengembangkan Nilai Moral Pada Anak (Jakarta: Elex Media Komputindo, 2009). 
Akhlak mulia merupakan kecerdasan spiritual siswa yang harus ditingkatkan karena dengan nilai-nilai spiritual dapat menjadi landasan kokoh untuk mengembangkan berbagai keterampilan lainnya. Akhlak mulia sendiri dapat dilihat dari tingkat ketaqwaannya terhadap Allah SWT. Taqwa adalah pelaksanaan atas semua perintah Allah dengan perasaan senang dan cinta karena ridho-Nya yang juga merupakan tanggung jawab sebagai umat manusia.

\section{Kesimpulan}

Akhlak mulia sangat berperan penting dalam mewujudkan tujuan pendidikan. Akhlak adalah suatu perbuatan baik yang muncul pada diri sendiri. Tanpa akhlak yang baik maka ilmu pengetahuan yang diperoleh akan sia-sia karena ilmu itu tidak hidup dalam masyarakat. Pendidikan di Indonesia telah mengarah pada pembentukan akhlak mulia pada siswa agar menghasilkan generasi yang mampu meningkatkan mutu SDM. Dalam lembaga pendidikan terutama pada proses pembelajaran membutuhkan strategi yang tepat yaitu strategi bercerita dengan teknik role playing untuk mengembangkan akhlak mulia siswa. Strategi bercerita dengan teknik role playing adalah cara dalam proses pembelajaran dengan menggunakan cerita dan bermain peran untuk menanamkan dan mengembangkan ilmu pengetahuan serta akhlak mulia. Dengan tercapainya Akhlak mulia pada siswa dapat mengembangkan ilmu-ilmu pengetahuan lain. Dibuktikan dengan perilaku yang baik dalam memperlakukan buku serta guru sebagai sumber belajar siswa. Siswa yang berakhlak mulia akan jadi output yang sangat berguna bagi masyarakat untuk tercapainya kesejahteraan dan kedamaian. 


\section{Referensi}

Baihaqi, Imam. 'Peningkatan Keterampilan Bermain Drama Dengan Metode Role Playing Pada Kelompok Teater Kenes SMPN 4 Yogyakarta'. Transformatika: Jurnal Bahasa, Sastra, Dan Pengajarannya 12, no. 2 (2016): 15-28.

Baroroh, Kiromim. 'Upaya Meningkatkan Nilai-Nilai Karakter Peserta Didik Melalui Penerapan Metode Role Playing'. Jurnal Ekonomi \& Pendidikan 8, no. 2 (2011).

Dian Ibung. Mengembangkan Nilai Moral Pada Anak. Jakarta: Elex Media Komputindo, 2009.

Hamzah B, Uno. Profesi Kependidikan, Problema, Solusi Dan Reformasi Di Indonesia. 7. Jakarta: Bumi Aksara, 2011.

Lickona, Thomas. Educating for Character: How Our Schools Can Teach Respect and Responsibility. New York: Bantam Books, 2009.

M, Dwi Bhakti Indri. 'Religious Spirituality - Cognitive Behaviour Therapy Untuk Meningkatkan Self-Confidence Dalam Social Interaction Anak Usia Dini'. Nidhomul Haq : Jurnal Manajemen Pendidikan Islam 1, no. 3 (2016): 162-78. https://doi.org/10.31538/ndh.v1i3.15.

Ma`arif, Muhammad Anas. 'Analisis Strategi Pendidikan Karakter Melalui Hukuman Preventif. Ta'allum: Jurnal Pendidikan Islam 6, no. 1 (6 March 2018): 31-56. https://doi.org/10.21274/taalum.2018.6.1.31-56.

- 'Pendidikan Islam Dan Tantangan Modernitas'. Nidhomul Haq: Jurnal Manajemen Pendidikan Islam 1, no. 2 (26 March 2016): 4758.

Ma'arif, Muhammad Anas. 'Hukuman (Punishment) Dalam Perspektif Pendidikan Di Pesantren'. Ta'allum: Jurnal Pendidikan Islam 5, no. 1 (1 June 2017): 1-20. https://doi.org/10.21274/taalum.2017.5.1.1-20.

Mekarningsih, Ni Kadek Ayu, Nyoman Wirya, and Mutiara Magta. 'Penerapan Metode Bercerita Berbantuan Media Audio Visual Untuk Meningkatkan Kemampuan Berbahasa Lisan Pada Anak'. Jurnal Pendidikan Anak Usia Dini Undiksha 3, no. 1 (2015).

Mursid. Pengembangan Pembelajaran PAUD. Bandung: Remaja Rosdakarya, 2015.

Putu, Pebri Damaryanti Ni, I. Made Tegeh, Putu Rahayu Ujianti, and S. Psi. 'Efektivitas Metode Bercerita Dengan Media Boneka Wayang Terhadap Kemampuan Bercakap-Cakap Anak 
Kelompok B Di Tk Widya Sesana Sangsit Tahun Pelajaran 2016/2017'. Jurnal Pendidikan Anak. Usia Dini Undiksha 5, no. 1 (2017).

Raharjo, Sabar Budi. 'Pendidikan Karakter Sebagai Upaya Menciptakan Akhlak Mulia'. Jurnal Pendidikan dan Kebudayaan 16, no. 3 (10 May 2010): 229-38. https://doi.org/10.24832/jpnk.v16i3.456.

Rahman, Muzdalifah M. Metode Bercerita Membentuk Kepribadian Muslim Pada Anak Usia Dini. ThufuLa, 2013.

Setiantono, Try. 'Penggunaan Metode Bercerita Bagi Anak Usia Dini Di Paud Smart Little Cilame Indahbandung'. Empowerment 1, no. 2 (2018): 18-23.

Syaiful Bahri, Djamarah, and Aswan Zain. Strategi Belajar Mengajar. Jakarta: Rineka Cipta, 2010.

Widianti, Ida Ayu Komang Sri, Ni Ketut Suarni, Nice Maylani Asril, and S. Psi. 'Penerapan Metode Bercerita Dengan Media Gambar Untuk Meningkatkan Keterampilan Berbicara Pada Anak'. Jurnal Pendidikan Anak Usia Dini Undiksha 3, no. 1 (2015).

Yulianti, Mega. 'Peranan Metode Bercerita Dalam Mengembangkan Nilai-Nilai Moral Pada Anak Di Kelompok B2 TK Pertiwi Palu'. Bungamputi 2, no. 3 (2012). 